\title{
Intestinal and hepatic coccidiosis among rabbits in Yogyakarta, Indonesia
}

\author{
Penny Humaidah Hamid ${ }^{1}$, Sigit Prastowo ${ }^{2}$ and Yuli Purwandari Kristianingrum ${ }^{1}$ \\ 1. Faculty of Veterinary Medicine, Universitas Gadjah Mada, Yogyakarta, Indonesia; 2. Department of Animal Science, \\ Universitas Sebelas Maret, Indonesia. \\ Corresponding author: Penny Humaidah Hamid, e-mail: penny_hamid@ugm.ac.id \\ Co-authors: SP: prastowo@staff.uns.ac.id, YPK: yuli_purwandari@mail.ugm.ac.id \\ Received: 27-01-2019, Accepted: 25-06-2019, Published online: 15-08-2019
}

doi: 10.14202/vetworld.2019.1256-1260 How to cite this article: Hamid PH, Prastowo S, Kristianingrum YP (2019)

Intestinal and hepatic coccidiosis among rabbits in Yogyakarta, Indonesia, Veterinary World, 12(8): 1256-1260.

\begin{abstract}
Background and Aim: The attention to rabbit meat production in Indonesia is comparatively less to other farm animals such as cattle and poultry industries. However, future prospect of rabbit to be seriously industrialized seemed quite promising due to rabbit is highly productive and has short reproduction cycle as well as generation interval. One of the diseases infecting many rabbits is coccidiosis caused by protozoan parasite, Eimeria spp. The infectious stage of Eimeria spp. presents ubiquitously in the environment and increases the risk of parasite transmission. Preventive methods such as vaccination are not yet fully developed, while sporadic treatment is not efficiently reduce the cases. In this study, Eimeria spp. infecting rabbits in Yogyakarta Province, Indonesia, were investigated with the aim for precise diagnosis to determine targeted treatment and as a baseline epidemiological data from rabbit in Indonesia.
\end{abstract}

Materials and Methods: Sample collection was performed randomly for 3 months, from March 2017 to May 2017 and covered areas in Yogyakarta, Indonesia. A total of 750 samples were collected. Eimeria species identification was determined morphologically from the samples after sporulation in $2.5 \%$ potassium dichromate by COCCIMORPH.

Results: Ten species of Eimeria spp. were identified in this study from the positive samples $(527 / 750 ; 70.3 \%)$. Eimeria flavescens was present in $80 \%$ of the positive samples, Eimeria coeciola in $78 \%$, Eimeria perforans in $61 \%$, Eimeria exigua in 37\%, Eimeria media in 33\%, Eimeria stiedae in 31\%, Eimeria irresidua in 12\%, Eimeria magna in 11\%, Eimeria intestinalis in 10\%, and Eimeria piriformis in 10\%. Coinfection as noted in $80 \%$ of the positive samples with $2-6$ species in a specimen. E. flavescens and E. coeciola were the most prevalent among all Eimeria $\mathrm{spp} .(\mathrm{p} \leq 0.0001)$.

Conclusion: Eimeria spp. is detected in high prevalence among rabbit in Yogyakarta, Indonesia, with commonly occurs in mixed infections. In this paper, we describe Eimeria spp. that are circulating in Indonesia and present it as updated information to farmers and veterinarians. To the best of our knowledge, we provide the first information about rabbit coccidiosis in Indonesia.

Keywords: coccidiosis, Indonesia, rabbit.

\section{Introduction}

The rabbit is a small animal belonging to lagomorphs, according to the digestive system, it is categorized as pseudoruminant that able to utilize large amounts of roughages by having large cecum and large intestine for microbial digestion. Further, rabbit could be easily raised for high-quality meat which known to be healthier than meat from other ruminant animals since its content is high in polyunsaturated fatty acids and many essential amino acids. Rabbit meat also provides high calories, but low of low-density lipoproteins and cholesterol levels, which is attracting more consumers with healthy lifestyle trends [1]. The world global production of rabbit meat is increasing with a rise in production from 1,224,186 tons in 2010 to $1,428,085$ tons in 2016 [2]. The largest

Copyright: Hamid, et al. Open Access. This article is distributed under the terms of the Creative Commons Attribution 4.0 International License (http://creativecommons.org/licenses/by/4.0/), which permits unrestricted use, distribution, and reproduction in any medium, provided you give appropriate credit to the original author(s) and the source, provide a link to the Creative Commons license, and indicate if changes were made. The Creative Commons Public Domain Dedication waiver (http://creativecommons.org/ publicdomain/zero/1.0/) applies to the data made available in this article, unless otherwise stated. production of rabbit meat in Asia is derived from China, which supplies $80 \%$ of Asia's demands [2]. In Europe, around 180 million rabbits are reared to supply meat consumption demands. Rabbits rank sixth for supporting meat consumption after poultry, laying hens, trout, salmon, and pigs [3].

At present, the attention to rabbit meat production in Indonesia is less when compared with other farm animals such as cattle and poultry. The total rabbit population in 2018 was 1,251,018 and was mostly concentrated on Java Island [4]. Indonesia may also consider heightening awareness of using rabbit as a source of good meat by reflecting on both the rabbit population and knowledge of the commercial industry in other countries. Since meat production is always below its large national demands, Indonesia has had to import cattle meat from aboard for years [5]. The managerial problem of the cattle industry leads to losses of meat productivity and, therefore, increases meat prices in society. Self-sufficient production of meat from cattle is not possible, mainly due to animal health issues and some managerial problems, coupled with losses in productivity [6]. Rabbit as a meat source can serve as a potential alternative to support the meat 
demand of 250 million people besides the meat from cattle, chicken, and fishes. Rabbit husbandry seems quite promising because rabbit is highly productive in terms of the number of resulted offspring, short gestation and lactation periods, and great prolificacy. It may produce $30-40$ young weaned offspring per doe annually in tropical climate with semi-intensive reproduction management [7]. Moreover, the investment and labor costs to initiate rabbit husbandry are relatively small and can be handled by most family members in the backyard. In addition to that, rabbits are easy to transport and market for food, fur, skin, and do not need a large amount of feed and housing space.

Coccidiosis is persistently one of the most important primary causes of digestive disease in fattening rabbits [8]. Coccidiosis not only has a direct impact on performance but also acts in synergy with epizootic rabbit enteropathy [8]. Rabbit coccidiosis or eimeriosis is caused by the apicomplexan parasite, Eimeria spp. To date, 17 different Eimeria species have been described that infect rabbits worldwide [9]. Eimeria spp. always present on rabbit farms, are found ubiquitously in the environment, and are virtually impossible to eradicate. Therefore, knowledge of coccidiosis remains of utmost importance. Eimeria spp. infects the host orally with the infective stage, i.e., a sporulated oocyst. The sporozoite enters the endothelial or epithelial cell of the host intestine and forms schizogony processes [10]. The newly developed merozoites will infect neighboring cells and undergo gametogony. Later, oocysts will be passed with fecal samples and develop further sporogony process in the environment [10]. During this schizogony process and cell rupture due to merozoites egress, clinical manifestations can be observed due to disorders in feed metabolism. Eimeria stiedae infections are characterized by endogenous development within the rabbit epithelium of the bile duct. This specific site of development stage results in specific pathological changes as known as hepatic coccidiosis.

A trial of vaccination using selected precocious lines of Eimeria spp. has been introduced to prevent rabbit coccidiosis with promising results on a laboratory scale $[11,12]$. However, production on a large or commercial scale to be applied in the field is still far away due to the time required by processes including optimization, registration, safety, and distribution to customers. It is not recommended to perform sporadic treatment since it does not efficiently reduce environmental contamination with infectious oocysts and potent parasite transmission. In Indonesia, many farmers are not familiar with infectious gastrointestinal diseases mainly caused by protozoa in rabbits. Coccidiosis usually occurs without any clinical or nonspecific symptoms. The correct diagnosis is the critical point in choosing a treatment and reducing coccidiosis cases in the field.

In this study, Eimeria spp. infecting rabbits in Yogyakarta Province, Indonesia, were investigated with the aim for precise diagnosis to determine targeted treatment and as a baseline epidemiological data from rabbit in Indonesia.

\section{Materials and Methods \\ Ethical approval}

Ethical Clearance regarding necropsies of hepatic coccidiosis was issued by "Laboratorium Penelitian dan Pengujian Terpadu, Universitas Gadjah Mada", Indonesia ([LPPT UGM], no. 00047/04/ LPPT/IV/2017.

\section{Sample collection}

Sample collection was performed randomly for 3 months, from March to May 2017 in several districts of Kulonprogo, Bantul, and Sleman, Yogyakarta, Indonesia (included in the Special Region of Yogyakarta, $7^{\circ} 43^{\prime} 57.0^{\prime \prime} \mathrm{S}$ and $\left.110^{\circ} 20^{\prime} 11.0^{\prime \prime} \mathrm{E}\right)$. A total of 750 fecal samples were collected in plastic containers and stored at $4^{\circ} \mathrm{C}$ until the time of examination. In this study, feces were collected from rectums of rabbits reared in a group and fecal samples from individually caged rabbits. Along with that, rabbits with fecal samples containing E. stiedae oocysts were identified, and 23 rabbits were necropsied to confirm with histopathology analysis.

\section{Fecal sample processing}

Fecal samples were sedimented by short centrifugation $(36 \times \mathrm{g}, 5 \mathrm{~min})$. After sedimentation, the water was discharged and saturated $\mathrm{NaCl}$ was added to float the oocysts. Parasitological objects were observed microscopically under 400×. Oocysts per gram (OPG) of feces were counted for samples using the McMaster technique [13]. Briefly, $2 \mathrm{~g}$ of each sample was mixed in $30 \mathrm{ml}$ of salt solution at room temperature. Large debris was removed by pouring the fecal sample through a wire mesh. Then, $0.5 \mathrm{ml}$ of the suspension was added to a McMaster slide. Both chambers were observed under a light microscope using $100 \times$. Oocysts were counted by multiplying the total number of oocysts by 50 . Since the sample weights were varied and sampling was performed once per individual rabbit, we did OPG counts on samples with sufficient amounts only (257 from total of 527 positive samples). Identification of Eimeria species was performed after sporulation of positive samples in $2.5 \%$ potassium dichromate at room temperature. Eimeria species were identified under a microscope at $400 \times$. Eimeria species identification was determined morphologically from sporulated oocysts by COCCIMORPH (http://www.coccidia.icb.usp.br/coccimorph) software [14].

\section{Determination of hepatic samples of infected rabbits}

The livers from $E$. stiedae-infected rabbits were processed using hematoxylin-eosin staining to evaluate hepatic sample lesions.

\section{Statistical analysis}

In this study, we observed several parameters, namely, the prevalence and species variation of 
coccidiosis due to Eimeria spp. in both hepatic and intestinal forms. The species prevalence was expressed as a percentage and was determined by dividing the positively observed samples by the total number of positive samples. The species was identified morphologically then compared among species prevalence using analysis of variance at $\alpha=5 \%$.

\section{Results and Discussion}

The results of our study show that the prevalence of Eimeria spp. varied, i.e., Kulonprogo 68.6\% $(172 / 251)$, Bantul 78.38\% (184/234), and Sleman $63.79 \%(171 / 265)$. The prevalence of rabbit coccidiosis in all investigated areas was $70.26 \%$ (527/750). In this study, we observed both hepatic and intestinal coccidiosis in Indonesian rabbits.

Of the 17 Eimeria species that infect rabbits [9], we found that 10 species were circulating among investigated rabbits. Ten species of Eimeria spp. were identified from the infected samples $(\mathrm{n}=527)$ in this study, i.e., Eimeria flavescens $(80 \%, 421 / 527)$, Eimeria coeciola $(78 \%, 411 / 527)$, Eimeria perforans $(61 \%, 322 / 527)$, Eimeria exigua (37\%, 195/527), Eimeria media $(33 \%, 173 / 527)$, E. stiedae $(31 \%$, 165/527), Eimeria irresidua (12\%, 63/527), Eimeria magna (11\%, 58/527), Eimeria intestinalis (10\%, 53/527), and Eimeria piriformis (10\%, 53/527) (Figure-1). The prevalence was highest for E. flavescens and E. coeciola compared with the other Eimeria spp. $(\mathrm{p} \leq 0.0001)$. We also found specimens with co-infection of Eimeria spp. between single to 6 species in the positive samples. In total, specimens were co-infected with 1, 2, 3, 4, 5 and 6 species at 2, $10,43,27,11$ and $7 \%$ respectively (Figure-2). Rabbits with hepatic coccidiosis showed infiltration primarily of eosinophils and other polymorphonuclear cells in the liver parenchyma (Figure-3a) followed by severe inflammation around the biliary duct where $E$. stiedae developed (Figure-3b). Various developmental stages of $E$. stiedae were found within the biliary duct with a massive epithelial cell proliferation that was clearly observed (Figure-3b-d).

Recently, rabbits became popular as pet animals as well as meat sources in Indonesia. Although the rabbit industry is not as big as that for poultry or cattle, rabbit production is assumed to become more profitable in upcoming years [3]. Since the awareness of consuming non-red types of meat is increasing, rabbit meat is being considered as a delicacy and a healthy food product. In addition, it is easy to digest for daily consumption by both children and older adults [1]. However, information about rabbit diseases, especially coccidiosis, is still limited among farmers. To the best of our knowledge, we provide the first information about rabbit coccidiosis in several areas investigated on Java Island.

Rabbit coccidiosis is reported worldwide and affects different rabbit types with serious economic losses as consequences. Coccidiosis occurs both in

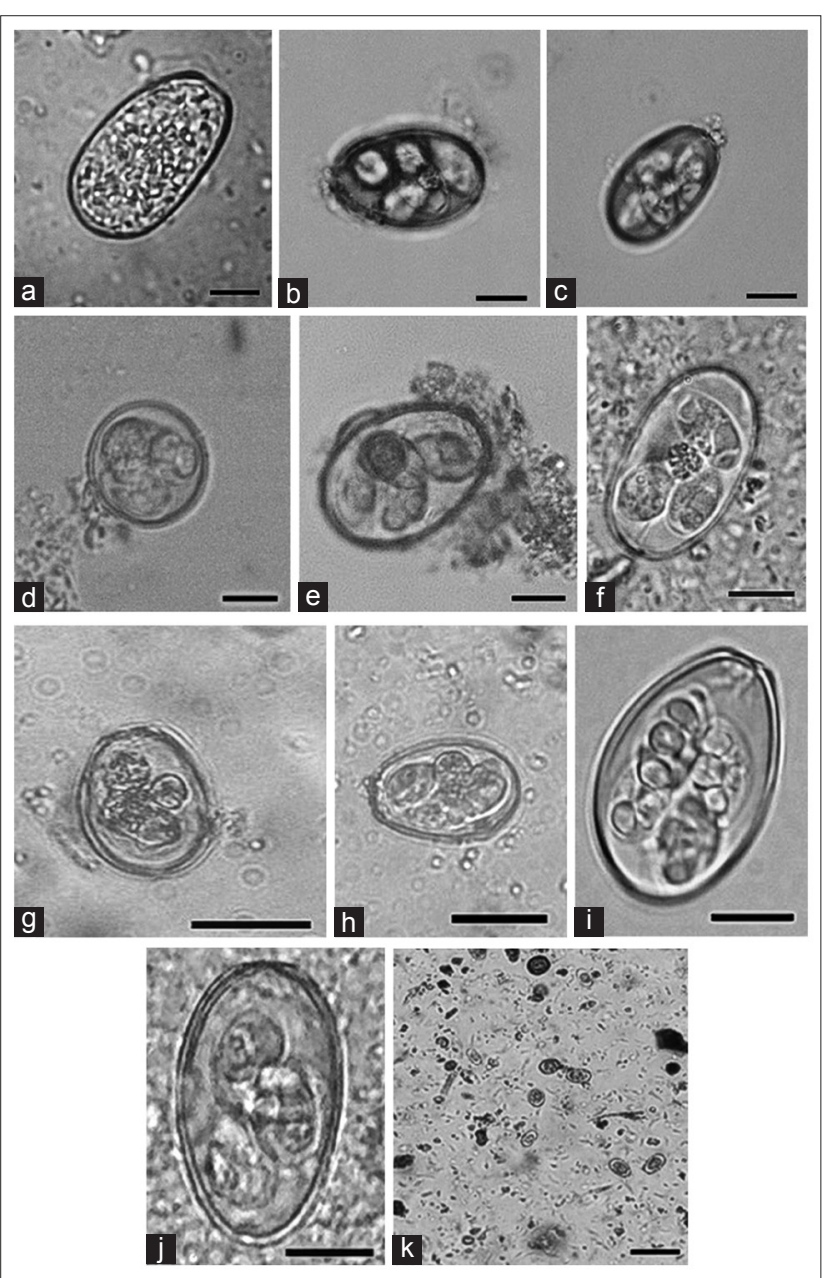

Figure-1: Eimeria spp. commonly circulate in Indonesia. (a) Unsporulated Eimeria stiedae from liver tissue squash, (b) Eimeria flavescens, (c) Eimeria coecicola, (d) Eimeria exigua, (e) Eimeria media, (f) Eimeria perforans, (g) Eimeria intestinalis, (h) Eimeria magna, (i) Eimeria piriformis, (j) Eimeria irresidua, (k) multiple species infection in a specimen. Scale bar $=10 \mu \mathrm{m}$.

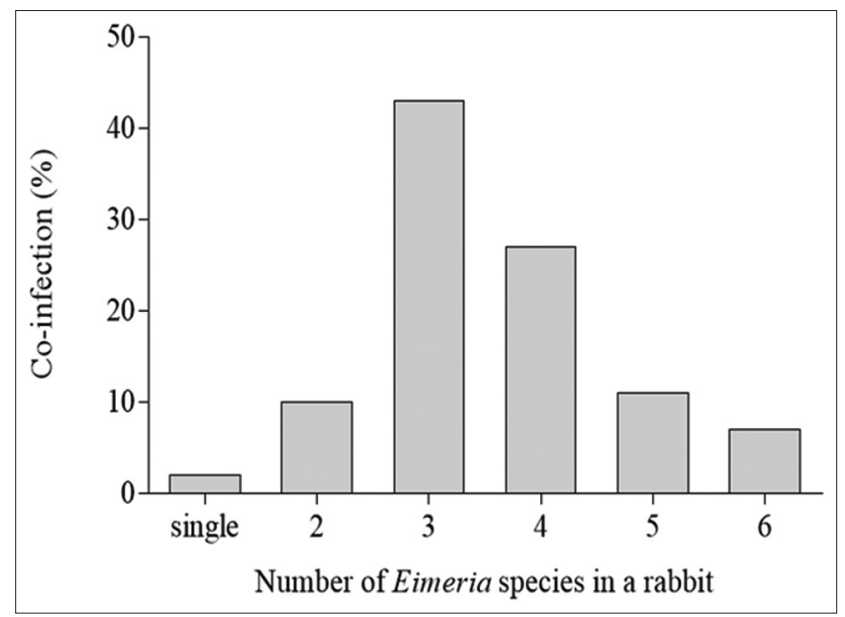

Figure-2: The percentage of co-infection between Eimeria spp. species which occurs in the rabbit population from Yogyakarta.

meat and fur types of rabbits in China, which supply more than $40 \%$ of the world's rabbit demands, with infection reaching $56.4 \%$ and E. perforans as the most 


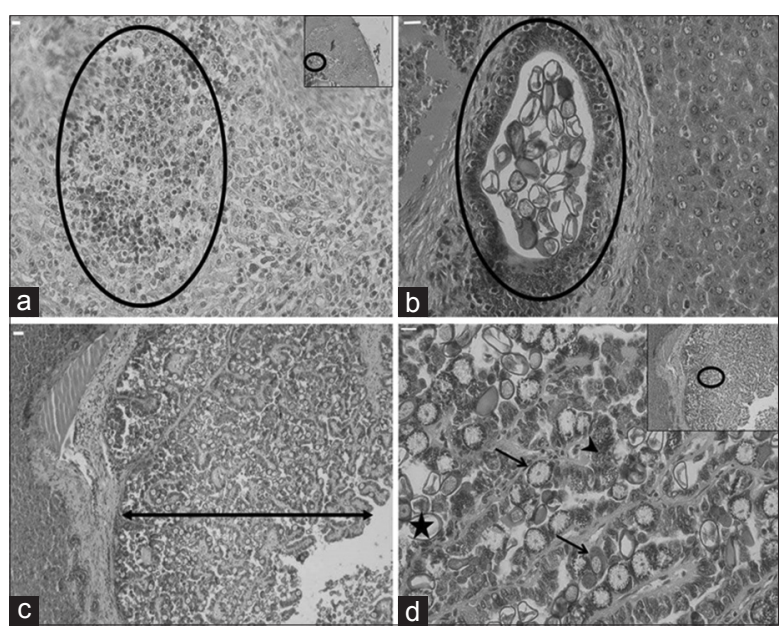

Figure-3: Severe hepatic coccidiosis lesion as indicated. (a) A complex of inflammatory cells in liver tissue (circle), (b) oocysts develop within the epithelium of the biliary duct and are detected in the biliary duct (circle), (c) massive proliferation of the epithelial line of the biliary duct (double-headed arrow), (d) intracellular development of Eimeria stiedae, macro- and micro-gamonts (arrows), schizogony process (arrowhead), developed oocyst (star). Scale bar $=10 \mu \mathrm{m}$.

prevalent [14]. E. perforans and E. flavescens were reportedly the two common species infecting wild rabbits in France [15]. In Egypt, the prevalence of natural infection among rabbit populations reached $70 \%$ with $E$. intestinalis and E. coecicola as predominant species [16]. Both intestinal and hepatic coccidiosis was also determined as the dominant parasitological cases $(78.83 \%)$ during the veterinary hygiene inspection in Poland [17].

The fecal condition in this investigation was divided into two categories, namely, hard fecal dropping/grapes-like cecotropes $(75 \%, 563 / 750)$ and watery-very soft cecotropes $(25 \%, 187 / 750)$. The presence of watery cecotropes is higher in young rabbits $<3$ months old $(67 \%, 125 / 187)$ compared with older groups more than 3 months old in common $(33 \%, 62 / 187)$. However, Eimeria spp., in this paper, did not always detect in these abnormal fecal conditions. Of $38 \%(200 / 527)$ of infected rabbits were aged $<3$ months and another $62 \%(327 / 527)$ infection occurred in rabbits more than 3 months old. Rabbit at $<3$ months old group were categorized as suckling and small-sized rabbits since there were no precise record of rabbit age from the farmers. Of $88 \%$ rabbits infected by Eimeria spp. in this report (464/527) did not show any clinical signs of gastrointestinal disorder such as bloat distended stomach or lethargy. The McMaster count of 257 positive samples showed that OPG $\leq 1000$ was found in $68 \%, \leq 5000$ was in $25 \%$, and $\geq 10,000$ was in $7 \%$. Since individual species of rabbit coccidia differ in their pathogenicity [18] and we did not separate the amount of the pathogenic from the non-pathogenic Eimeria species in mixed infections, we could not analyze the correlation of the species composition and the presence of pathological signs if rabbits were infected.
Besides specific and curative treatments for rabbit coccidiosis, several prevention strategies can be used to minimize the number of coccidiosis cases. The rabbit's biosecurity management by removing fecal oocysts sooner than they finish sporulation to be infective reduces the number of infective oocytes. However, the farmer cannot rely on the fecal disposal alone but must use anticoccidial drugs mixed in the food pellets or drinking water, the most common preventive method [19]. Although it still requires intense research and development, vaccination using a precocious line of agents seems to be quite promising for potential application in the near future $[10,11,18]$.

\section{Conclusion}

Eimeria spp. is detected in high prevalence among rabbit in Indonesia with commonly occurs in mixed infections. We describe Eimeria spp. that are circulating in Indonesia, provide information to both farmers and veterinarians, and suggest the significance of rabbit coccidiosis. To the best of our knowledge, we provide the first information about rabbit coccidiosis in Indonesia.

\section{Authors' Contributions}

PHH, YPK, and SP performed the experiments and analyzed the data. PHH and SP designed the study, coordinated the work, and wrote the manuscript. All authors read and approved the final manuscript.

\section{Acknowledgments}

The authors extend sincere gratitude to the local farmers in around Yogyakarta for permission to collect fecal sample of their rabbits. This research was supported by PTUPT grant number 2672/UN1. DITLIT/DIT-LIT/LT/2019 from Ministry of Research, Technology and Higher Education, Republic of Indonesia to PHH at fiscal year 2019.

\section{Competing Interests} interests.

The authors declare that they have no competing

\section{Publisher's Note}

Veterinary World remains neutral with regard to jurisdictional claims in published institutional affiliation.

\section{References}

1. Zotte, A.D. and Szendrő, Z. (2011) The role of rabbit meat as functional food. Meat Sci., 88(3): 319-331.

2. FAOSTAT. (2016) FAOSTAT. Available from: http://www. fao.org/faostat/en/\#data/QL. Accessed on 19-05-2019.

3. Directorate General for Health and Food Safety. (2017) Overview Report: Commercial Rabbit Farming in the European Union. Publication Office of the European Union. Luxembourg. Available from: http://www.ec.europa.eu/food/audits-analysis/overview_reports/act_getPDF. cfm?PDF ID=1193. Last accessed on 19-05-2019.

4. Directorate General of Livestock and Animal Health Resources. (2017) Rabbit Population by Province. Department of Agriculture, Republic of Indonesia, Jakarta. 
Available from: http://www.pertanian.go.id/Data5tahun/ ATAPNAK2017(pdf)/114-Pop_Kelinci_Prop.pdf. Accessed on 19-05-2019.

5. Directorate General of Livestock and Animal Health Resources. (2011) Rencana Strategis Direktorat Jenderal Peternakan dan Kesehatan Hewan 2010-2014. Department of Agriculture, Republic of Indonesia, Jakarta. Available from: http://www. ditjenpkh.pertanian.go.id/userfiles/download/Renstra_Ditjen PKH_(2010-2014).pdf?time $=1484186785022$. Last accessed on 19-05-2019.

6. Directorate General of Livestock and Animal Health Resources. (2017) Livestock and Animal Health Statistics. Department of Agriculture, Republic of Indonesia, Jakarta. Available from: http://www.ditjenpkh.pertanian. go.id/userfiles/File/Buku_Statistik_2017_(ebook).pdf?time $=1505127443012$. Accessed on 19-05-2019.

7. Lebas, F., Coudert, P., de Rochambeau, H. and Thébault, R.G. (1997) The Rabbit Husbandry, Health and Production. FAO Animal Production and Health Series No. 21. Rome, FAO.

8. Vancraeynest, D., De Gussem, M., Marien, M. and Maertens, L. (2008) The anticoccidial efficacy of robenidine hydrochloride in Eimeria challenged rabbits. In: Pathology and Hygiene. $9^{\text {th }}$ World Rabbit Congress June 10-13, Verona, Italy.

9. Duszynski, D.W. and Couch, L. (2013) The Biology and Identification of the Coccidia (Apicomplexa) of Rabbits of the World. Elsevier, Amsterdam.

10. Urquhart, G.M., Armour, J., Duncun, J.L., Dunn, A.M. and Jennings, F.W. (1996) Veterinary Parasitology. $2^{\text {nd }}$ ed. Blackwell Science Ltd., New Jersey.

11. Drouet-Viard, F., Coudert, P., Licois, D. and Boivin, M.
(1997) Acquired protection of the rabbit (Oryctolagus cuniculus) against coccidiosis using a precocious line of Eimeria magna: Effect of vaccine dose and age at vaccination. Vet. Parasitol., 69(3-4): 197-201.

12. Akpo, Y., Kpodekon, M.T., Djago, Y., Licois, D. and Youssao, I.A. (2012) Vaccination of rabbits against coccidiosis using precocious lines of Eimeria magna and Eimeria media in Benin. Vet. Parasitol., 184(1): 73-76.

13. Ministry of Agriculture FAF. (1986) Manual of Veterinary Parasitological Laboratory Techniques. $3^{\text {rd }}$ ed. Her Majesty's Stationery Office, London.

14. Kumar, S., Garg, R., Moftah,A., Clark, E.L., Macdonald, S.E., Chaudhry, A.S., Sparagano, O., Banerjee, P.S., Kundu, K., Tomley, F.M. and Blake, D.P. (2014) An optimized protocol for molecular identification of Eimeria from chickens. Vet. Parasitol., 199(1-2): 24-31.

15. Yin, G., Goraya, M.U., Huang, J., Suo, X., Huang, Z. and Liu, X. (2016) Survey of coccidial infection of rabbits in Sichuan Province, Southwest China. Springerplus, 5(1): 870.

16. Gres, V., Voza, T., Chabaud, A. and Landau, I. (2003) Coccidiosis of the wild rabbit (Oryctolagus cuniculus) in France. Parasite, 10(1): 51-57.

17. El-Shahawi, G.A., El-Fayomi,H.M. andAbdel-Haleem,H.M. (2012) Coccidiosis of domestic rabbit (Oryctolagus cuniculus) in Egypt: Light microscopic study. Parasitol. Res., 110(1): 251-258.

18. Pakandl, M. (2009) Coccidia of rabbit: A review. Folia Parasitol. (Praha), 56(3): 153-166.

19. Szkucik, K., Pyz-Lukasik, R., Szczepaniak, K.O. and Paszkiewicz, W. (2014) Occurrence of gastrointestinal parasites in slaughter rabbits. Parasitol. Res., 113(1): 59-64.

$* * * * * * * *$ 